\title{
Implementasi Kebijakan Kawasan Tanpa Rokok (KTR) di Kabupaten Sumbawa
}

\author{
Apriadi $^{1}$, Budi Kurniawan ${ }^{2}$ Topan Rahmatul Iman ${ }^{3}$ \\ ${ }^{1}$ Universitas Teknologi Sumbawa \\ ${ }^{2}$ Universitas Teknologi Sumbawa \\ ${ }^{3}$ Universitas Teknologi Sumbawa
}

\section{INFORMASI ARTIKEL}

Sejarah Artikel

Diterima Redaksi: 20 Juli 2019

Revisi Akhir: 1 Agustus 2019

Diterbitkan Online: 30 Agustus 2019

\section{KATA KUNCI}

Implementasi, Kawasan Tanpa Rokok,
Sumbawa
KORESPONDENSI

No HP: 082116654416

E-mail: apriadi.lanandrang@uts.ac.id

\begin{abstract}
A B S T R A C T
The magnitude of the impact of smoking on health and the high number of smokers in Indonesia, prompted the government of the Republic of Indonesia to make policies related to this. Sumbawa Regency as one of the regencies in West Nusa Tenggara Province is participating in realizing a non-smoking area by passing regional regulation number 7 of 2016. But smoking activities are still often found in public transportation, children's playground areas, in health and education service facilities in Sumbawa Regency. The purpose of this study is to find out how the implementation of regional regulation number 7 of 2016 on No Smoking Areas (KTR) in Sumbawa Regency. The research method used is a qualitative research method with a descriptive approach, which describes the implementation of the policy of no-smoking area in Sumbawa Regency. The results of this study are the implementation of policies on nonsmoking areas in Sumbawa Regency which are not yet running, the Regional Organization of Organizations (OPD) which have a connection in the implementation of these regulations do not understand the mechanism of implementing these regulations so that there are no programs or activities in related agencies that are trying to realize and encourage the creation of a non-smoking area in Sumbawa.
\end{abstract}

\section{PENDAHULUAN}

Pemberdayaan Nikotin, tar dan karbon monoksida (CO) merupakan salah satu dari beberapa zat kimia yang ada dalam sebatang rokok. Apabila zat-zat ini dikonsumsi secara berkelanjutan maka akan berdampak buruk pada kesehatan terutama dapat memicu kanker (Kemenkes, 2011, h.2). Dalam banyak kasus yang telah di teliti, ditemukan bahwa pada tahun 2003 sekitar 4,9 juta orang di negara berkembang meninggal dunia karena rokok. Kematian yang disebabkan oleh rokok ini menjadi tingkat kematian yang lebih besar dari kematian akibat penyakit malaria, kematian maternal, dan TBC (Arina \& Sulatri, 2011, h.696). Bahkan faktor utama penyebab dari penyakit paru obstruktif kronik adalah berasal dari rokok (Rahmadi, et al., 2013, h.25).

Aktifitas merokok sangat sering kita jumpai di area publik, angkutan umum dan beberapa fasilitas layanan kesehatan dan pendidikan, terutama di daerah-daerah yang belum menerapkan kebijakan kawasan tanpa rokok. Hasil penelitian yang dirilis oleh Lembaga Demografi Universitas Indonesia tahun 2013, perokok aktif Indonesia mencapai 61,4 juta orang (Salim, 2013, h.58). Perokok aktif tidak hanya dari kalangan usia tua namun juga remaja dan anak-anak, sejak tahun 2013 hingga 2018 tingkat merokok pada remaja meningkat sangat signifikan, yaitu 7,2\% (2013), 8,8 \% (2016), dan 9.1\% pada tahun 2018 (Tirtosastro \& Murdiyati, 2010, h.34).

Dampak dari aktifitas merokok tidak hanya merugikan bagi kesehatan perokok aktif namun juga bagi orang yang berada di sekitar perokok tersebut (perokok pasif) yang menghirup udara yang telah tercampur dengan asap rokok tersebut. Besarnya dampak aktifitas merokok bagi kesehatan masyarakat dan tingginya angka perokok di Indonesia, mendorong pemerintah Republik Indonesia untuk membuat kebijakan terkait hal tersebut, melalui Peraturan Pemerintah Nomor 19 Tahun 2003 pemerintah mengatur tentang kadar dari kandungan rokok, penggunaan label keterangan kandungan rokok dan himbauan mengenai dampak dari rokok serta mengenai kawasan bebas rokok. Lahirnya peraturan daerah tentang kawasan tanpa rokok di berbagai daerah merupakan salah satu upaya pemerintah daerah untuk menjalankan PP tersebut. Kabupaten Sumbawa juga ikut serta mendorong upaya 
mewujudkan kawasan tanpa rokok di Kabupaten Sumbawa melalui peraturan daerah (Perda) nomor 7 tahun 2016.

Perda tersebut mengatur tentang larangan merokok di berbagai kawasan, yaitu Kawasan fasilitas pelayanan kesehatan, tempat proses belajar-mengajar, tempat bermain anak, tempat ibadah, angkutan umum, perkantoran, dan tempat umum. Pada Pasal 13 ayat 2 pada Perda tersebut berbunyi "setiap orang/badan dilarang memproduksi, menjual, mengiklankan, dan/atau mempromosikan rokok dan/atau produk tembakau di kawasan tanpa rokok". Sehingga secara regulasi atau kebijakan sudah jelas bahwa baik penjual maupun perokok aktif diwajibkan untuk patuh dan taat kepada peraturan agar tidak menimbulkan dampak atau bahaya bagi lingkungan dan masyarakat sekitar. Disamping itu, sejak 2017 Kabupaten Sumbawa juga sedang berupaya mewujudkan Kabupaten Layak Anak (Pemkab Sumbawa, 2017).

Namun, aktifitas merokok di area publik di Sumbawa masih banyak ditemui, belum tersedianya lokasi "Smoking Area" di fasilitas umum seperti di terminal dan fasilitas pendidikan menjadikan perokok aktif bebas merokok dimanapun. Hal ini menjadi menarik untuk diteliti, dimana kebijakan tentang kawasan tanpa rokok sudah ada, namun masih ditemukan aktifitas merokok di area yang dilarang. Berlandaskan kondisi tersebut, maka penelitian ini bertujuan untuk mengetahui impelemntasi Peraturan daerah Nomor 7 Tahun 2016 tentang Kawasan Tanpa Rokok di Kabupaten Sumbawa.

\section{Rokok dan Dampak Bagi Kesehatan}

Merokok pada dasarnya adalah menikmati asap nikotin yang dibakar. Selain nikotin, di dalam rokok juga terdapat senyawa gula, bahan aditif, saus, pemberi rasa, aroma, dan lain-lain sehingga terbentuk rasa yang memenuhi selera konsumen (perokok). Satu batang rokok terdiri atas berbagai jenis tembakau agar rasa dan aroma yang diperoleh mempunyai kekhasan tersendiri. Bahan tambahan untuk rasa dan aroma yang lain berasal dari luar tembakau antara lain cengkeh dan mentol ((Tirtosastro \& Murdiyati, 2010, h.34).

Kandungan kimia tembakau yang sudah teridentifikasi jumlahnya mencapai 2.500 komponen, sedangkan dalam asap terdapat 4.800 macam komponen. Dari komponen kimia ini telah diidentifikasi yang membahayakan kesehatan adalah tar, nikotin, gas $\mathrm{CO}$, dan NO yang dihasilkan oleh tanaman tembakau (Kemenkes, 2011, h.2). Dari jumlah bahan kimia berbahaya tersebut, 1100 bahan lainnya akan menjadi asap tanpa berubah atau terpecah menjadi zat lain melalui pembakaran (Tirtosastro \& Murdiyati, 2010, h.34). Di Indonesia sendiri telah mengupayakan penekanan pada perilaku merokok masyarakatnya. Seperti yang tertuang dalam Undang-Undang Republik Indonesia Nomor 32 Tahun 2010 tentang Larangan Merokok. Dalam Undang-Undang tersebut telah dijelaskan tentang bahaya merokok bagi kesehatan baik bagi perokok aktif maupun perokok pasif dan larangan pada masyarakat untuk tidak merokok di tempat umum atau tempat yang telah di tentukan sebagai kawasan tanpa rokok.

Disamping itu, Pemerintah juga telah melakukan tindakan pencegahan dan peringatan melalui pesan peringatan atau pesan bahaya merokok pada setiap bungkus rokok yang di produksi di Indonesia. Ketentuan ini telah di atur dalam Peraturan Pemerintah Nomor 109 Tahun 2012 tentang Pengamanan Bahan yang Mengandung Zat Adiktif Berupa Produk Tembakau Bagi Kesehatan. Ketentuan ini mengatur atau mengrontrol setiap produk tembakau atau rokok yang beredar untuk wajib mencantumkan pesan bahaya atau peringatan bagi kesehatan. Hal ini terbukti dari pesan atau himbauan yang tertulis di dalam kemasan rokok yang beredar di Indonesia yaitu "Merokok dapat menyebabkan kanker, serangan jantung, impotensi, gangguan kehamilan dan janin”, dan kini pesan tersebut telah diubah dan dipertegas lagi dengan "Merokok membunuhmu" dan ditambahkan pula dengan foto-foto mengerikan yang merupakan dampak dari merokok tersebut (Widati, 2013, h.105).

\section{Prinsip Dasar dan Tujuan Kawasan Tanpa Rokok}

Kawasan Tanpa Rokok merupakan sebuah ruangan atau area yang dinyatakan dilarang untuk berbagai macam kegiatan merokok maupun kegiatan memperjual-belikan rokok, promosi rokok, dan mengiklankan produk tembakau atau rokok. Tujuan dari diberlakukannya aturan Kawasan Tanpa Rokok ini adalah untuk pemenuhan hak masyarakat untuk hidup sehat, menghirup udara segar yang terbebas dari asap rokok, meningkatkan kualitas kesehatan masyarakat, serta meningkatkan produktifitas masyarakat (Kemenkes, 2010, h.16).

Indonesia merupakan salah satu negara yang turut menaruh perhatian lebih terhadap penggunaan rokok tembakau. Telah banyak perangkat-perangkat aturan yang ditetapkan sebagai pedoman untuk mencegah dan menanggulangi dampak buruk dari rokok. Sejak tahun 2003 peraturan mengenai rokok telah di atur dalam Peraturan Pemerintah (PP) Nomor 19 Tahun 2003. Di dalam peraturan tersebut, telah di atur secara terperinci mengenai kadar dari kandungan rokok dan pemeriksaan yang harus dilakukan untuk membatasi jumlah nikotin dan tar yang diperbolehkan sesuai dengan peraturan, peraturan mengenai kewajiban penggunaan label keterangan kandungan dari rokok dan himbauan mengenai dampak 
dari kegiatan merokok tersebut, peraturan mengenai pembatasan dan pengendalian penjualan dan produksi rokok, peraturan mengenai iklan dan promosi rokok, serta peraturan mengenai Kawasan Tanpa Rokok (KTR). Pada Pasal 22, 23,24 dan Pasal 25 dalam peraturan tersebut mengenai Kawasan Tanpa Rokok, selain menjabarkan mengenai kawasan-kawasan yang harus terbebas dari kegiatan merokok, namun juga mengatur mengenai penyediaan ruangan atau lokasi khusus bagi para perokok aktif, serta mewajibkan pemerintah daerah untuk mewujudkan kawasan tanpa rokok di daerahnya.

Aturan mengenai Kawasan Tanpa Rokok juga terdapat dalam Peraturan Bersama Menteri Kesehatan dan Menteri Dalam Negeri Nomor 188 Tahun 2011 dan Nomor 07 Tahun 2011 tentang Pedoman Pelaksanaan Kawasan Tanpa Rokok (KTR). Dalam peraturan ini menjelaskan tentang pengertian atau definisi dari Kawasan Tanpa Rokok, tujuan dari dibuatnya aturan Kawasan Tanpa Rokok, tugas instansi pemerintah dan masyarakat dalam memerangi rokok dan patuh pada aturan Kawasan Tanpa Rokok,

\section{METODOLOGI}

Metode penelitian yang digunakan adalah metode penelitian kualitatif dengan pendekatan deskriptif, yaitu mendeskripsikan implementasi tentang kebijakan kawasan tanpa rokok di Kabupaten Sumbawa. Lokasi penelitian ini adalah di Sumbawa Besar, lokasi tersebut dipilih karena ibukota kabupaten Sumbawa. Data yang digunakan dalam penelitian ini adalah data primer dan skunder, data skunder diperoleh dari desk study yaitu dengan mengumpulkan hasil-hasil kajian terdahulu, laporan-laporan kegiatan di daerah yang berhubungan dengan kebijakan KTR dan laporan program kerja OPD yang terkait. Sementara itu, data primer diperoleh melalui observasi lapangan dan wawancara mendalam ke beberapa dinas terkait yaitu Dinas Kesehatan, Dinas Pendidikan, Dinas Komunikasi dan Informasi dan Dinas Pekerjaan Umum dan Tata Ruang Kabupaten Sumbawa.

\section{HASIL DAN PEMBAHASAN}

Implementasi Kawasan Tanpa Rokok (KTR) di Kabupaten Sumbawa

Sumbawa Besar merupakan salah satu kabupaten dari sepuluh kabupaten yang ada di Provinsi Nusa Tenggara Barat, dengan luas wilayah sebesar $6.643,98 \mathrm{~km} 2$ dan memiliki jumlah penduduk mencapai sekitar 449.680 jiwa (Pemkab Sumbawa, 2018). Dengan jumlah penduduk yang cukup padat di wilayah kota, menjadi perlu pemerintah daerah kabupaten Sumbawa memperhatikan kebersihan udara untuk menjaga kesehatan 34 Apriadi serta pembinaan dan pengawasan terhadap pelaksanaan Kawasan Tanpa Rokok di Indonesia. Kemudian peraturan-peraturan tersebut dijadikan sebagai pegangan atau pedoman bagi instansi pemerintah daerah dalam merumuskan aturan Kawasan Tanpa Rokok di daerahnya.

Pelaksanaan Kawasan Tanpa Rokok di Indonesia tergolong cukup baik. Terlihat dari jumlah daerah maupun provinsi yang telah melaksanakan peraturan Kawasan Tanpa Rokok tersebut yakni mencapai 19 Provinsi dan 309 Kabupaten atau Kota di Indonesia (Greeners.co, 2018). Dari jumlah keseluruhan yakni 34 provinsi, lebih dari setengah provinsi telah melaksanakan peraturan tersebut. Bahkan sebanyak 309 kabupaten/kota dari 415 kabupaten/kota yang tercatat telah menerapkan aturan tersebut. Jumlah ini membuktikan bahwa pelaksanaan dari peraturan Kawasan Tanpa Rokok ini secara regulasi telah dilaksanakan sesuai dengan pedoman yang ada. Dengan adanya peraturan mengenai Kawasan Tanpa Rokok diberbagai daerah di Indonesia, menjadikan pencapaian tujuan yang diharapkan oleh pemerintah semakin nyata. masyarakatnya. Dengan ditetapkanya Peraturan Daerah (Perda) Nomor 7 tahun 2016, maka pemerintah daerah memberikan perlindungan kepada masyarakat akan dampak dari rokok dan asap yang dihasilkan dari proses pembakaran rokok tersebut, menjaga kelestarian lingkungan dan pasokan udara yang bersih dari asap rokok di kabupaten sumbawa, dan meningkatkan taraf hidup masyarakat agar dapat lebih produktif dengan hidup sehat terbebas dari dampak negatif dari kegiatan merokok di Kabupaten Sumbawa, serta mencegah perokok pasif atau masyarakat yang tidak merokok agar tidak turut menjadi perokok aktif.

Sejak ditetapkan Perda tersebut pada tahun 2016, implementasi dari kebijakan ini dapat diuraikan sebagai berikut berdasarkan 3 kawasan yaitu:

\section{a) Lingkungan fasilitas layanan kesehatam;}

Kawasan fasilitas layanan kesehatan yang menjadi area yang ditetapkan sebagai kawasan tanpa rokok adalah rumah sakit, rumah bersalin, klinik kesehatan, puskesmas dan yang termasuk didalamnya, balai pengobatan, laboratorium, apotek, posyandu, tempat praktek kesehatan swasta, dan fasilitas kesehatan lainnya. Pada tahun 2017 dinas Kesehatan menerbitkan Keputusan Kepala Dinas Kesehatan Kabupaten Sumbawa Nomor 20628 tentang Penetapan Area Kawasan Tanpa Rokok Dan Tempat Khusus Merokok Di Lingkup Kantor Dinas Kesehatan Sumbawa. Peraturan tersebut menjelaskan mengenai penetapan kawasan tanpa rokok yang terfokus atau terkhusus hanya pada lingkungan di kantor Dinas Kesehatan saja. Sementara aturan tentang area kawasan Implementasi Kebijakan Kawasan 
tanpa rokok dan lokasi khusus merokok di fasilitas kesehatan lainnya tidak tersedia.

Namun, berdasarkan pengamatan penelitian di lapangan, telah tersedia beberapa poster tentang himbauan dan peringatan dilarang merokok di beberapa puskesmas dan RSUD Sumbawa (Gambar 1). Tetapi tempat khusus merokok di fasilitas layanan kesehatan belum tersedia.

Gambar 1

Lokasi Poster Peringatan dan Himbauan Dilarang Merokok di lingkup Dinas Kesehatan Sumbawa

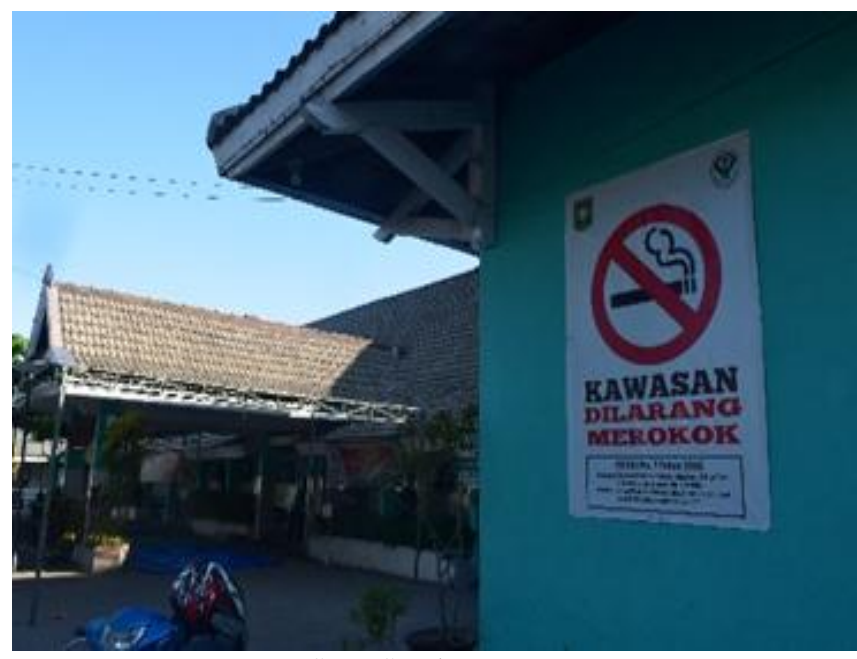

RSUD Sumbawa Besar

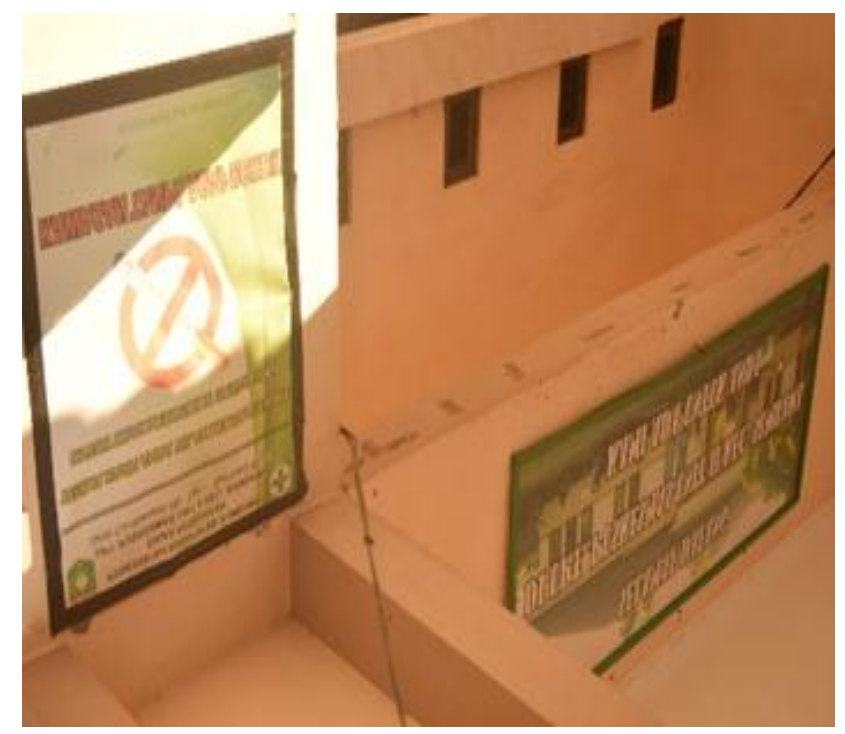

Puskesmas Brangbiji

Sementara itu, langkah yang telah dilakukan oleh Dinas Kesehatan dalam mendorong terwujudnya kawasan tanpa rokok di fasilitas layanan kesehatan masih ditahap sosialisasi, adapun kegiatan sosialisasi tersebut terlaksana hanya dalam forum dimana dihadiri oleh perwakilan 24 kecamatan, namun belum ada kegiatan sosialisasi dan monitoring secara langsung ke lapangan. Disamping itu, dari observasi yang dilakukan oleh peneliti, didapati beberapa poster dan spanduk mengenai himbauan atau peringatan dilarang merokok dalam kondisi rusak, terkelupas, atau bahkan telah robek (Gambar 2). Sehingga himbauan tersebut sudah tidak dapat terbaca dan tidak terlihat oleh masyarakat ataupun pengunjung di sekitar kawasan tersebut. permasalahan-permasalahan teknis seperti inilah yang akan menurunkan tingkat efektifitas dari peringatan yang berusaha dimunculkan dalam spanduk atau poster tersebut. Disisilainnya, pemilihan media yang tepat dan penempatan yang mudah dijangkau akan mempengaruhi perhatian masyarakat terhadap isi atau pesan yang berusaha disampaikan dengan menggunakan media tertentu seperti spanduk ataupun poster (Setiadi, 2016, h.4).

\section{Gambar 2}

Spanduk atau Poster Yang Telah Tidak Layak

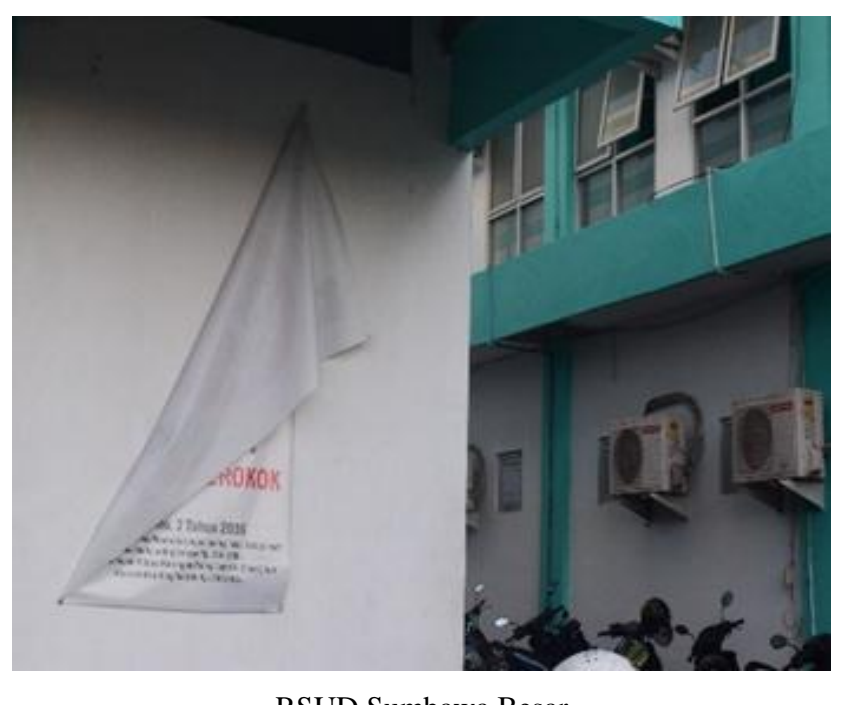

Pengimplementasian kawasan tanpa rokok di lingkungan fasilitas kesehatan belum berjalan maksimal, salah satu faktornya adalah lemahnya pengawasan dan kooridinasi antara dinas kesehatan dengan layanan fasilitas kesehatan yang ada seperti RSUD dan Puskesmas. Sehingga program maupun kegiatan yang bertujuan mewujudkan kawasan tanpa rokok di fasilitas kesehatan belum terpenuhi dengan baik.

\section{b) Lingkungan fasilitas layanan pendidikan;}

Pemenuhan hak masyarakat akan lingkungan dengan kualitas udara yang segar dan sehat tidak hanya menjadi tanggungjawab dari Dinas Kesehatan, namun juga harus menjadi perhatian bagi setiap instansi yang memiliki keterkaitan dengan kawasan-kawasan yang tertera dalam Peraturan Daerah Nomor 07 Tahun 2016 di Kabupaten Sumbawa. seperti halnya dalam penanganan kawasan 
yang termasuk bagian dari Dinas Pendidikan Kabupaten Sumbawa, yaitu lingkungan fasilitas belajar mengajar baik sekolah formal maupun informal.

Menurut Kepala Bidang Sekolah Menengah Pertama, Dinas Pendidikan Kabupaten Sumbawa bahwa keterlibatan Dinas Pendidikan Kabupaten Sumbawa terkait kebijakan kawasan tanpa rokok di kabupaten Sumbawa, saat ini hanya sebatas sosialisasi dan himbauan kepada kepala sekolah di masing-masing sekolah untuk menghimbau kepada jajarannya agar tidak melakukan kegiatan merokok secara sembarangan. Sehingga dinas pendidikan masih bertindak secara pasif karena kerjasama serta tindakan pengawasan secara langsung di lapangan masih belum ada.

Sementara itu, berdasarkan pengamatan lapangan media berupa rambu-rambu dan stiker himbauan sudah tersedia di beberapa sekolah namun belum secara menyeluruh. Penggunaan stiker dengan kalimat "Dilarang Merokok" dan "Kawasan Bebas Asap Rokok" ditemukan di lokasi-lokasi tertentu. Namun tata letak dari stiker dan rambu-rambu tersebut dirasa masih kurang maksimal. Sebagian besar dari stiker tersebut diletakkan pada area yang tidak mudah terlihat. Sama halnya dengan yang terjadi di instansi kesehatan, stiker dan rambu maupun spanduk yang terpampang sudah banyak yang tidak layak dan sudah rusak. Ukuran stiker yang terlalu kecil juga menjadi alasan tidak efektifnya himbauan tersebut (Gambar 3).

Gambar 3

Stiker Himbauan tentang KTR di Sekolah

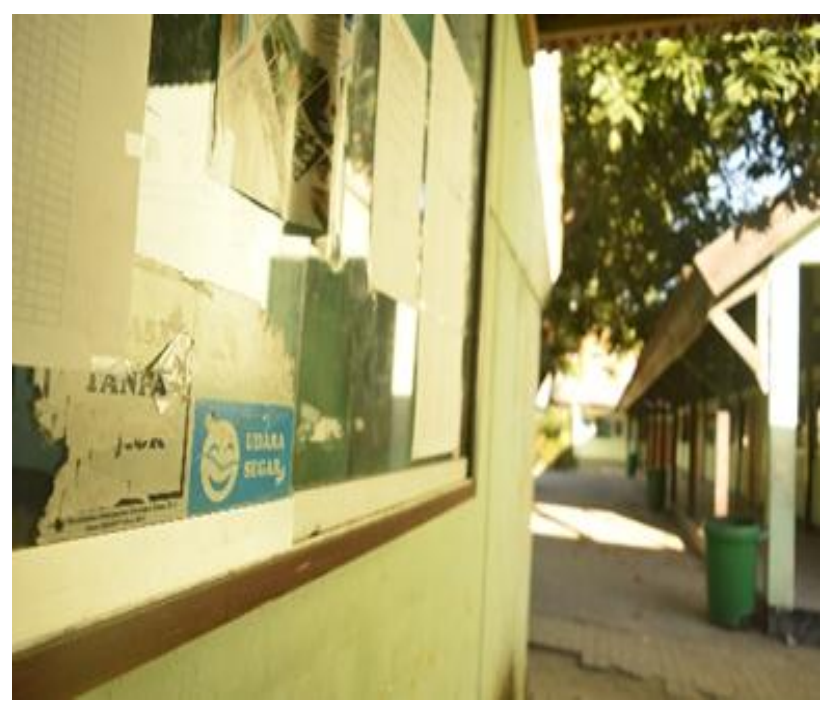

SMP Negeri 1 Labuhan Badas

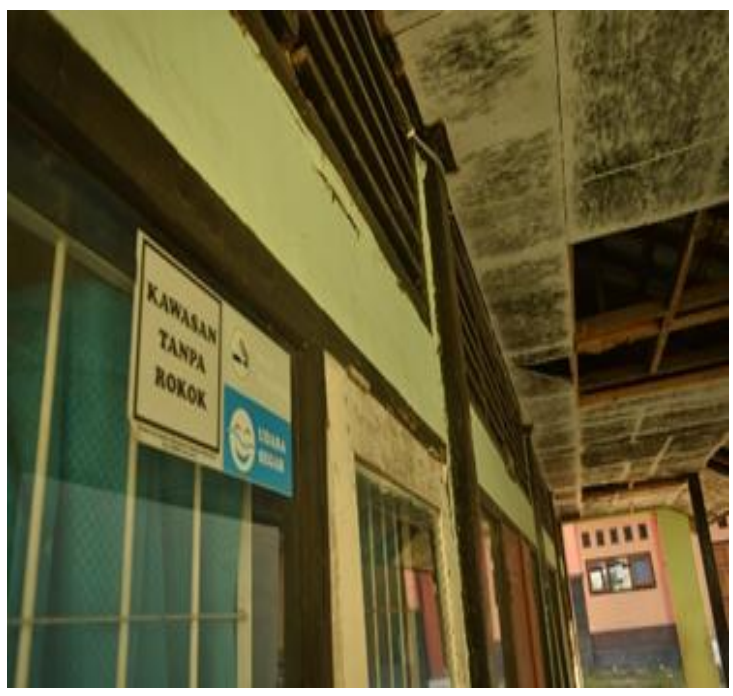

SMP Negeri 2 Sumbawa Besar

c) Lingkungan kawasan publik dan taman bermain anak;

Implementasi kebijakan kawasan tanpa rokok di area publik dan taman bermain anak di kabupaten Sumbawa belum berjalan, hal ini tampak dari masih banyaknya kegiatan merokok yang terjadi di sekitar kawasan taman kota maupun taman bermain anak. Berdasarkan pengamatan lapangan, kegiatan merokok tersebut bahkan dilakukan secara terang-terangan tanpa adanya pengawasan dan teguran di berbagai lokasi taman kota dan taman bermain anak di Kabupaten Sumbawa yaitu Taman Mangga, Taman Kerato, Taman Lapangan Pahlawan, Taman Genang Genis, Pantai Jempol.

Disamping itu, perihal penggunaan media informasi atau himbauan berupa spanduk atau stiker dan semacamnya, masih jauh dari kata maksimal. Sejauh pantauan peneliti, keberadaan dari spanduk atau stiker tersebut masih belum ditemukan di Taman Mangga, Taman Kerato, Taman Lapangan Pahlawan, Taman Genang Genis, Pantai Jempol. Selain belum adanya himbauan di taman kota dan taman bermaain anak masih banyak ditemukan kios penjualan rokok di lokasi tersebut, serta adanya aktifitas promosi rokok dengan diperankan oleh para wanita-wanita berpakaian ketat yang menjajakan rokok dagangan mereka. Sehingga implementasi kebiajakn kawasan tanpa rokok masih jauh dari ketentuan yang telah ditetapkan dalam Perda Nomor 7 tahun 2016.

\section{SIMPULAN}

Implementasi peraturan Kawasan Tanpa Rokok di Sumbawa yang diamanatkan dalam Peraturan Daerah Nomor 7 Tahun 2016 masih belum berjalan dengan baik, salah satu faktor kurang maksimalnya penerapan kebijakan Kawasan Tanpa Rokok ini adalah kurangnya koordinasi antara Dinas Kesehatan dengan dinas 
lainnya yang turut berperan dalam mewujudkan kawasan tanpa rokok di kabupaten Sumbawa. Bentuk sosialisasi yang dilakukan oleh dinas terkait masih belum efektif karena sosialisasi yang dilakukan tidak terstruktur dan tidak terjadwal, melainkan hanya disaat dibutuhkan saja.

Terdapat beberapa poster, stiker, maupun papan peringatan yang sudah tidak layak pakai dan tidak mudah terlihat dikeramaian. Sementara itu, ukuran stiker yang tergolong kecil menjadi salah satu faktor sulitnya peringatan tersebut dapat terlihat. Kemudian hambatan lain yang membuat kebijakan tersebut tidak berjalan adalah penyediaan akan sarana atau lokasi khusus bagi para perokok aktif masih sangat minim, atau bahkan hampir tidak ada. Lokasi-lokasi yang masuk dalam Kawasan Tanpa Rokok di Sumbawa hampir tidak ditemukan lokasi yang dikhususkan bagi para perokok aktif untuk menyalurkan kegiatan merokoknya. Kurangnya pengawasan atas kegiatan merokok di sekitar kawasan tanpa rokok menjadikan para perokok tersebut dengan bebas merokok disekitar kawasan tanpa rokok.

\section{DAFTAR PUSTAKA}

Arina \& Sulastri. (2011). Hubungan antara dukungan orang tua, teman sebaya dan iklan rokok dengan perilaku merokok pada siswa laki-laki madrasah aliyah negeri 2 boyolali. Gaster, 8 (1), 695-705.

Kementerian Kesehatan. (2011). Informasi tentang penanggulangan masalah merokok melalui radio. Jakarta: Kementerian Kesehatan.

Kementerian Kesehatan. (2010). Pedoman Pengembangan Kawasan Tanpa Rokok. Jakarta: Kementerian Kesehatan.

Rahmadi, A., dkk. (2013). Hubungan pengetahuan dan sikap terhadap rokok dengan kebiasaan merokok siswa smp di kota padang. Jurnal Kesehatan Andalas, 2 (1), 25-28.

Salim, A. D. (2013). Imc: Promosi, iklan dan sponsor rokok strategi perusahaan menggiring remaja untuk merokok. Jurnal Managemen dan Bisnis, 17 (1), 58-65.

Setiadi, A. (2016). Pemanfaatan media sosial untuk efektifitas komunikasi. Cakrawala Jurnal Humaniora, 16 (2), 1-7.

Tirtosastro, S., \& Murdiyati. (2010). Kandungan kimia tembakau dan rokok. Buletin Tanaman Tembakau, 2 (1), 33-43.

Undang-Undang Republik Indonesia Nomor 32 Tahun 2010 tentang Larangan Merokok

Peraturan Pemerintah Nomor 109 Tahun 2012 tentang Pengamanan Bahan yang Mengandung Zat Adiktif Berupa Produk Tembakau Bagi Kesehatan 